\title{
Hydrogeochemical characteristics and groundwater quality assessment for drinking and irrigation purposes in the Mazar-i-Sharif city, North Afghanistan
}

\author{
Ali Mahaqi ${ }^{1} \cdot$ Mohammad Mehdi Moheghi $^{2} \cdot$ Marzieh Mehiqi ${ }^{3} \cdot$ Mohmmad Anvar Moheghy ${ }^{4}$
}

Received: 4 December 2016 / Accepted: 17 July 2018 / Published online: 6 August 2018

(c) The Author(s) 2018

\begin{abstract}
The Mazar-i-Sharif city is part of the Balkh province, north of Afghanistan, and its groundwater resources are developed for water supply and irrigation purposes. The main lithological units consist chiefly of evaporite, conglomerate, sandstone, siltstone, and loess. In order to evaluate the quality of groundwater in the study area, 28 samples were collected and analyzed for various ions. Chemical indices like sodium adsorption ratio, the percentage of sodium, residual sodium carbonate and permeability index were calculated. Based on the analytical results, groundwater in the area is generally very hard, brackish, high to very high saline, and alkaline in nature. The abundance of the major ions is as follows: $\mathrm{Cl}^{-}>\mathrm{HCO}_{3}{ }^{-}>\mathrm{SO}_{4}{ }^{2-}>\mathrm{NO}_{3}{ }^{-}$ and $\mathrm{Na}^{+}>\mathrm{Ca}^{2+}>\mathrm{Mg}^{2+}>\mathrm{K}^{+}$. The dominant hydrochemical facies of groundwater is the $\mathrm{Na}-\mathrm{Cl}$ type, and alkalis $\left(\mathrm{Na}^{+}, \mathrm{K}^{+}\right)$ and strong acids $\left(\mathrm{Cl}^{-}, \mathrm{SO}_{4}{ }^{2-}\right)$ are slightly dominating over alkali earths $\left(\mathrm{Ca}^{2+}, \mathrm{Mg}^{2+}\right)$ and weak acids $\left(\mathrm{HCO}_{3}{ }^{-}, \mathrm{CO}_{3}{ }^{2-}\right)$. About $67 \%$ of the samples were showing a high concentration of nitrate, exceeding permissible limit of WHO (50 mg/l). The sources of $\mathrm{NO}_{3}{ }^{-}$in the study area are anthropogenic activities (domestic wastewater infiltration from the cesspits) and intense agricultural practices in nearby areas (Balkh district) of the city that utilize nitrogen and sulfate fertilizers. The chemical quality of groundwater is related to the dissolution of minerals, ion exchange, anthropogenic activities, and the residence time of the groundwater in contact with rock materials. The results of calculation saturation index by computer program PHREEQC show that nearly all of the water samples were supersaturated with respect to carbonate minerals (calcite and dolomite) and under-saturated with respect to sulfate minerals (gypsum and anhydrite). Assessment of water samples from various methods indicated that groundwater in the study area is chemically unsuitable for drinking and agricultural uses.
\end{abstract}

Keywords Groundwater quality $\cdot$ Mazar-i-Sharif city $\cdot$ Hydrogeochemical processes $\cdot$ Saturation index

Ali Mahaqi

ali.mahaqi@stu.um.ac.ir

Mohammad Mehdi Moheghi

M.moheghi@gmail.com

Marzieh Mehiqi

Marziemoheqi@gmail.com

Mohmmad Anvar Moheghy

Moheghy@gmail.com

1 Department of Geology, Ferdowsi University of Mashhad, Mashhad, Iran

2 Agriculture Faculty, Herat University, Herat, Afghanistan

3 Faculty of Agriculture, University of Tehran, Tehran, Iran

4 Department of Geology, Bamiyan University, Bamiyan, Afghanistan

\section{Introduction}

Deficiency of water is a problem in many countries. This problem has recently become more serious due to the disparity of rainfall caused by global warming. Utilization of well water for drinking will, therefore, become more important in the future (Kato et al. 2016). The access to safe drinking water is essential to human health (Karanth 1987); it is one of the basic human rights and the constituent of an effective health protection policy (Shygonskyi and Shygonska 2016). Afghanistan is rich in water even though it is at least mainly semiarid steppe lands or desert, mainly because at the top of the watershed in this region, the Kohi Baba, Hindu Kush, and Afghan Pamir are covered by snow in winter and provide vital meltwaters. Over $80 \%$ of the country's water resources have their origin in mountains $>2000 \mathrm{~m}$, which function as a natural storage of snow and ice that supports 
perennial flow in all major rivers in summer (Shroder 2014). Underground water is a critical resource for the continued development of the Afghanistan economy and for improvements to the health of the Afghan people, both within the growing urban population and the agricultural areas. The economic lifeblood of Afghanistan is agrarian based, with more than $80 \%$ of the Afghan people working in agriculture with arable land comprising only $12 \%$ of the total land area (Shroder and Ahmadzai 2016).

The Mazar-i-Sharif city (MSC) is located in the northern part of Afghanistan (within Afghan-Tajik Basin) about $425 \mathrm{~km}$ north of the country's capital, Kabul. It is surrounded by Uzbekistan in the north, Sari Pul and Jowzjan Provinces in the southwest and Kunduz Province in the east. The study area covers an area of $100 \mathrm{~km}^{2}$. Topographically, the state ranges in elevation from 320 to $420 \mathrm{~m}$ asl, with a gentle slope toward the Amu Darya River. MSC's population has increased greatly during the last 10 years and accommodates 650,000 inhabitants (USAID 2009). Some geological and hydrological studies were carried out in MSC city area by Miskin (1968), Russian Scientists (1969-1997) and Radojicic and Arsalan (1979), Afghan Geological Survey (AGS), as well as other international and local NGOs mainly for the development of water supplies and similar purposes. Nevertheless, most of the information that emanated from those studies had been lost over the years due to the prolonged wars. The developing residential in the study area and the increasing population growth has caused serious problems, particularly groundwater pollution and overabstraction. In the all supply wells within MSC, particularly during the summer season, the water level drops. As a result, residents of MSC facing serious drinking water problems.

In this study, for the first time, major ions of groundwater resources of MSC were investigated and interpreted thoroughly. Also, the potential hazard of nitrate $\left(\mathrm{NO}_{3}{ }^{-}\right)$and fluoride $\left(\mathrm{F}^{-}\right)$content in MSC's wells was analyzed. This paper could help international experts in environmental geochemistry to have a preliminary imagination of hydrochemistry status in North Afghanistan. Also, because of major water quality projects in Afghanistan were done by international NGOs and consulting firms, this will provide a rewarding database for their future projects and researchers in this subject.

\section{Geology and hydrogeology setting}

According to Ruleman et al. 2007, Afghanistan is situated in the southern margin of the Eurasian plate postulated during the Permian-Triassic times. It comprises three thick sedimentary rock regions, namely: Northern Afghanistan Basin (NAB), Southwestern Afghanistan Basin, and Southeastern Katawaz region. The area of MSC is mostly situated within the NAB. The Afghan-Tajik Basin is located in the desert and semidesert areas of southwest Uzbekistan, southeastern Tajikistan, and Northern Afghanistan (Ulmishek 2004). Northern Afghanistan has a pre-Jurassic unconformable basement overlain by Jurassic to Paleocene oil- and gas-bearing terrigenous and carbonate rocks, which in turn are unconformable and overlain by Neocene orogenic continental clastic rocks (Brookfield and Hashmat 2001). The MSC area contains Mesozoic to Cenozoic rocks of approximately seven or eight kilometers thick (Dastyar et al. 1990). The lithological characteristics of the Quaternary sediments and rocks in MSC are shown in Table 1.

The geological units of direct interest to the study area are the Quaternary-aged alluvial, proluvial deposits and salt marsh sediments, non-marine sediments and have formed when runoff gathered in swamp-like areas so because of high temperature and following precipitation formed them, covering Afghan North Plain (Fig. 1). According to Ashworth 2005, the Quaternary deposits in the study area can be divided into two main units, like alluvium deposits (Hilly area) and comprise terrace sands and gravels, with occasional cobbles and proluvial deposits cover most of the area.

The prevailing climate in MSC is semiarid and arid (Fig. 2). There is little rainfall throughout the year. In MSC, the average annual temperature is $21^{\circ} \mathrm{C}$ and annual precipitation is $170 \mathrm{~mm}$. With an average of $36.5^{\circ} \mathrm{C}$, July is the hottest month. The lowest average temperature in the year occurs in December, when it is around $4.3{ }^{\circ} \mathrm{C}$ (Ashworth 2005).

In MSC, water for irrigation and drinking is provided from two main sources, namely groundwater from shallow and deep aquifers and surface water from the Nahri-Shahi stream. The shallow aquifer is considered to be divided into two zones brackish water and freshwater. In the north

Table 1 Geological units and their characteristics in the study area

\begin{tabular}{lll}
\hline Geological unit & Characteristics & Age \\
\hline Q4a & Conglomerate and sandstone; alluvium, detrital sediments, gravel and sands & Holocene \\
Q4sm & Mud, silt, clay, more abundant than sand; limestone, gypsum, and salt & Holocene \\
Q34a & Conglomerate and sandstone; alluvium, detrital sediments, gravel and sands & Holocene-late Pleistocene \\
Q3a & Conglomerate and sandstone; detrital sediments, gravel and sands & Late Pleistocene \\
Q2loe & Loess; loess content more than sand and clay & Middle Pleistocene \\
\hline
\end{tabular}


Fig. 1 Geological map of Mazar-I-Sharif city (USGS 2005)

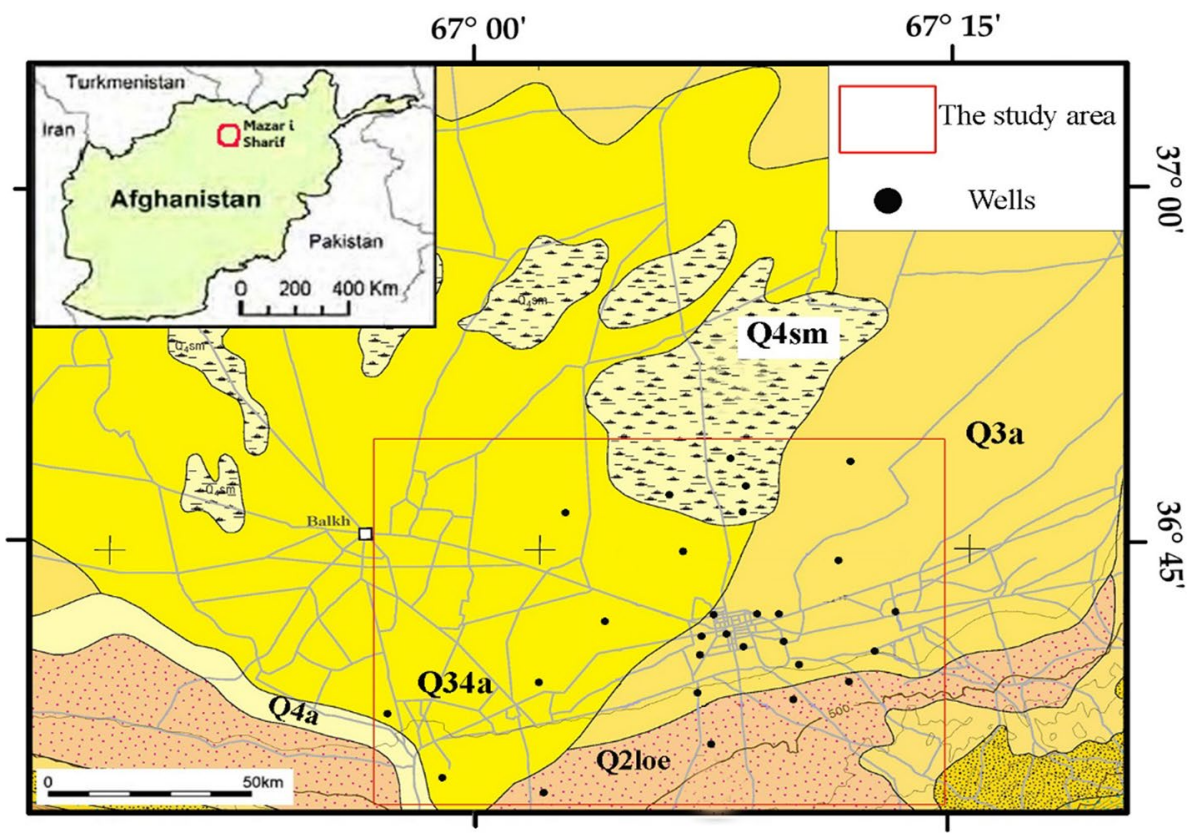

Methodology

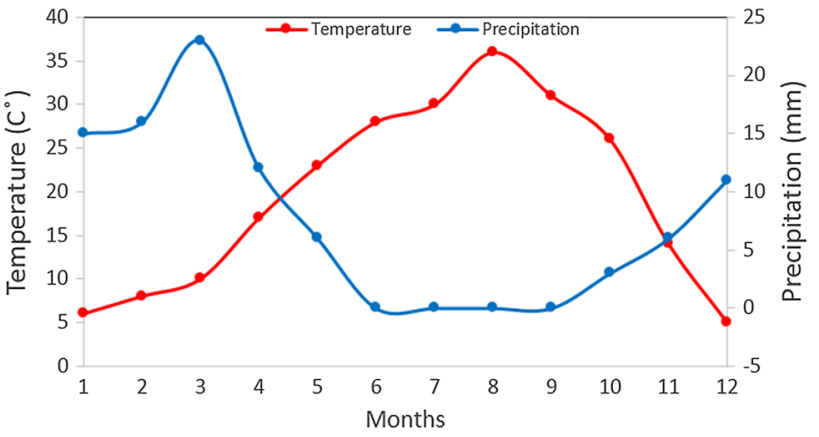

Sampling was carried out by water supply department from 28 hand-pumped wells during July 2014. Water samples were collected in $150 \mathrm{ml}$ dark glass bottles. $\mathrm{pH}$, total dissolved solids (TDS) and electrical conductivity (EC) were measured in the field by multiparameter VWR symphony SP90M5. Calcium $\left(\mathrm{Ca}^{2+}\right)$ and magnesium $\left(\mathrm{Mg}^{2+}\right)$ [measured by titration with ethylenediaminetetraacetic acid (EDTA)], sodium $\left(\mathrm{Na}^{+}\right)$ and potassium $\left(\mathrm{K}^{+}\right)$(determined by flame photometry), chloride $\left(\mathrm{Cl}^{-}\right)$(measured by Argentometric method) and sulfate $\left(\mathrm{SO}_{4}{ }^{2-}\right)$ (determined by turbidimetric methods), bicarbonate $\left(\mathrm{HCO}_{3}{ }^{-}\right)$(determined by titration with $\left.\mathrm{HCl}\right)$, nitrate $\left(\mathrm{NO}_{3}{ }^{-}\right)$ (determined by Spectrophotometer methods), and $\mathrm{F}^{-}$(determined by ion-sensitive electrodes) were analyzed in the Irrigation Department of MSC, where cations and anions are expressed in mequiv/l. All analyses reported in this study have ion balance $<5 \%$. Sodium absorption ratio (SAR), sodium percent $(\% \mathrm{Na})$, saturation index (SI), residual sodium carbonate (RSC) and permeability index (PI) were calculated using equations in Table 2. Saturation indices of the water samples were calculated for different minerals using the PHREEQC code (Parkhurst and Appelo 1999).

\section{Results and discussion}

\section{Groundwater chemistry}

The statistical characteristics of all the groundwater samples are presented in Table 3. The overall groundwater $\mathrm{pH}$ and EC values of the study area are ranged from 6.6 to 8.4 ply purposes. 
Table 2 Equations used in calculating SAR, \% Na, SI, RSC, and PI

\begin{tabular}{lll}
\hline Equation & Parameter & References \\
\hline a & $\mathrm{SAR}=\frac{\mathrm{Na}^{+}}{\sqrt{\frac{\mathrm{Ca}_{2}^{2+}+\mathrm{Mg}^{2+}}{2}}}$ & Richard (1954) \\
& & \\
b & $\% \mathrm{Na}=\frac{\left(\mathrm{Na}^{+}+\mathrm{K}^{+}\right)}{\left(\mathrm{Ca}^{2+}+\mathrm{Mg}^{2+}+\mathrm{Na}^{+}+\mathrm{K}^{+}\right)} * 100$ & Wilcox (1955) \\
c & $\mathrm{SI}=\log \frac{\mathrm{IAP}}{\mathrm{KT}}$ & $\begin{array}{c}\text { Garrels and } \\
\text { Mackenzie } \\
\end{array}$ \\
& & $(1967)$ \\
d & $\mathrm{RSC}=\left(\mathrm{CO}_{3}^{2-}+\mathrm{HCO}_{3}^{-}\right)$ & Eaton (1950) \\
& $-\left(\mathrm{Ca}^{2+}+\mathrm{Mg}^{2+}\right)$ & \\
e & $\mathrm{PI}=100 *\left[\left(\left[\mathrm{Na}^{+}\right]+\left[\mathrm{HCO}_{3}^{-}\right] 1 / 2\right)\right]$ & Ragunath (1987) \\
& $/\left[\mathrm{Na}^{+}\right]+\left[\mathrm{Ca}^{2+}\right]+\left[\mathrm{Mg}^{2+}\right]$ & \\
\hline
\end{tabular}

Table 3 Summary statistics of the analytical data and groundwater samples of the study area exceeding the permissible limits prescribed by WHO for drinking purposes

\begin{tabular}{|c|c|c|c|c|}
\hline Parameter & Min & Max & Mean & $\begin{array}{l}\text { Guideline } \\
\text { values WHO } \\
\text { (2011) }\end{array}$ \\
\hline $\mathrm{pH}$ & 6.6 & 8.4 & 7.7 & $6.5-8.5$ \\
\hline $\mathrm{EC}(\mu \mathrm{S} / \mathrm{cm})$ & 1003 & 6235 & 3495 & 1500 \\
\hline $\operatorname{TDS}\left(\mathrm{mg} \mathrm{l}^{-1}\right)$ & 667 & 4021 & 2310 & 1000 \\
\hline $\mathrm{Ca}^{2+}\left(\mathrm{mg} \mathrm{l}^{-1}\right)$ & 57 & 293 & 161 & 200 \\
\hline $\mathrm{Mg}^{2+}\left(\mathrm{mg} \mathrm{l}^{-1}\right)$ & 34 & 199 & 78 & 150 \\
\hline $\mathrm{Na}^{+}\left(\mathrm{mg} \mathrm{l}^{-1}\right)$ & 71 & 1120 & 471 & 200 \\
\hline $\mathrm{K}^{+}\left(\mathrm{mg} \mathrm{l}^{-1}\right)$ & 1.13 & 32 & 11 & 20 \\
\hline $\mathrm{HCO}_{3}^{-}\left(\mathrm{mg} \mathrm{l}^{-1}\right)$ & 207 & 1493 & 479 & 240 \\
\hline $\mathrm{Cl}^{-}\left(\mathrm{mg} \mathrm{l}^{-1}\right)$ & 119 & 1607 & 637 & 250 \\
\hline $\mathrm{SO}_{4}^{-2}\left(\mathrm{mg} \mathrm{l}^{-1}\right)$ & 119 & 1254 & 490 & 250 \\
\hline $\mathrm{NO}_{3}^{-}\left(\mathrm{mg} \mathrm{l}^{-1}\right)$ & 42 & 96 & 59 & 50 \\
\hline $\mathrm{CO}_{3}{ }^{2-}$ & 0 & 52 & 10 & - \\
\hline $\mathrm{F}^{-}$ & 0.009 & 0.063 & 0.026 & 1.5 \\
\hline $\mathrm{TH}$ & 327 & 1719 & 724 & - \\
\hline SAR & 1.3 & 19.1 & 7.6 & - \\
\hline$\% \mathrm{Na}$ & 26 & 81 & 55 & - \\
\hline RSC & -32.4 & 5.5 & -6.46 & - \\
\hline PI & 43 & 84 & 63.7 & - \\
\hline SI calcite & -1.08 & 1.51 & 0.35 & - \\
\hline SI dolomite & -0.73 & 2.95 & 0.85 & - \\
\hline SI gypsum & -3.52 & -0.32 & -1.17 & - \\
\hline SI anhydrate & -3.27 & -0.51 & -1.34 & - \\
\hline
\end{tabular}

and 1003 to $6235 \mu \mathrm{S} / \mathrm{cm}$, respectively. The large variation in EC is mainly attributed to geochemical processes prevailing in this region. TDS in the study area vary from 667 to $4021 \mathrm{mg} / \mathrm{l}$. The groundwater in the study area falls under fresh (TDS $<1000 \mathrm{mg} / \mathrm{l}$ ) to brackish (TDS $>1000 \mathrm{mg} / \mathrm{l}$ ) types of water (Freeze and Cherry 1997). The total hardness (as $\mathrm{CaCO}_{3}$ ) ranges from 327 to $1719 \mathrm{mg} / \mathrm{l}$. Cation concentrations and ratios can trace water-rock interaction processes, such as mineral weathering and cation exchange
(Han et al. 2009). In the study area, the $\mathrm{Na}^{+}$and $\mathrm{K}^{+}$concentrations in groundwater range from 71 to 1120 and 1.13 to $32 \mathrm{mg} / \mathrm{l}$, respectively. High concentrations of $\mathrm{Na}^{+}$in the groundwater are attributed to cation exchange among minerals. The concentrations of calcium range from 57 to $293 \mathrm{mg} / \mathrm{l}$, which is derived from calcium-rich minerals like calcite, dolomite, and gypsum. The major source of $\mathrm{Mg}^{2+}$ in the groundwater is due to ion exchange of minerals in rocks and soils by water. The concentrations of $\mathrm{Mg}^{2+}$ found in the groundwater samples vary in the range 34-199 mg/l. The $\mathrm{CO}_{3}{ }^{2-}$ and $\mathrm{HCO}_{3}{ }^{-}$concentration in groundwater are derived from carbonate weathering as well as the dissolution of carbonic acid in the aquifers (Kumar et al. 2009; Eq. 1).

$$
\begin{aligned}
& \mathrm{CaCO}_{3}+\mathrm{CO}_{2}+\mathrm{H}_{2} \mathrm{O} \rightarrow 2 \mathrm{HCO}_{3}^{-} \\
& \mathrm{CO}_{2}+\mathrm{H}_{2} \mathrm{O} \rightarrow \mathrm{H}^{+}+\mathrm{HCO}_{3}^{-}
\end{aligned}
$$

$\mathrm{HCO}_{3}{ }^{-}$in the study area ranges from 207 to $1493 \mathrm{mg} / \mathrm{l}$. The concentration of $\mathrm{Cl}^{-}$ranges from 119 to $1607 \mathrm{mg} / \mathrm{l}$ and increases from the recharge to discharge area. $\mathrm{SO}_{4}{ }^{2-}$ varies from 119 to $1254 \mathrm{mg} / \mathrm{l}$. High values of $\mathrm{SO}_{4}{ }^{2-}$ in groundwater indicated that $\mathrm{SO}_{4}{ }^{2-}$ derived from chemical fertilizers constituted an additional sulfate source. Furthermore, dissolution of sulfate-bearing minerals, especially gypsum and anhydrite that present in the formations is another cause of high content of $\mathrm{SO}_{4}{ }^{2-}$ in groundwater samples. In the study area, $\mathrm{NO}_{3}{ }^{-}$concentrations in samples ranged from 42 to $96 \mathrm{mg} / \mathrm{l}$. The major source of $\mathrm{NO}_{3}{ }^{-}$in the groundwater is agricultural activities, septic tanks, and human and animal wastes. Because there is no systematic sewage collection and treatment or refuse collection, the groundwater is affected by considerable contamination and the associated hygiene problems. In terms of land use pattern, in MSC and specifically adjacent area, there are vast farmlands and intense agricultural activity. Also, animal husbandry is one of the main activities among people, and then these practices have a significant contribution on $\mathrm{NO}_{3}{ }^{-}$content of water samples. The mean $\mathrm{F}^{-}$of samples is $0.063 \mathrm{mg} / \mathrm{l}$ with values ranging from 0.009 to $0.063 \mathrm{mg} / \mathrm{l}$. These values are found to be within the prescribed limit of WHO guideline, $1.5 \mathrm{mg} / \mathrm{l}$, so there is no potential hazard of $\mathrm{F}^{-}$content in groundwater samples in MSC. Figure 3 shows that $\mathrm{Na}^{+}$and $\mathrm{Cl}^{-}$are dominant cations and anion, respectively. A further illustration of this is shown in Fig. 3, where the median values of $\mathrm{Cl}^{-}$exceeded 50\% of total anions in the mille-equivalent unit. The abundance of the major ions in groundwater is in the following order: $\mathrm{Na}^{+}>\mathrm{Ca}^{2+}>\mathrm{Mg}^{2+}>\mathrm{K}^{+}$and $\mathrm{Cl}^{-}>\mathrm{HCO}_{3}{ }^{-}>\mathrm{SO}_{4}{ }^{2-}>\mathrm{NO}_{3}{ }^{-}$.

Minimum, maximum, and average values of physical and chemical parameters of groundwater samples are presented in Table 3. 


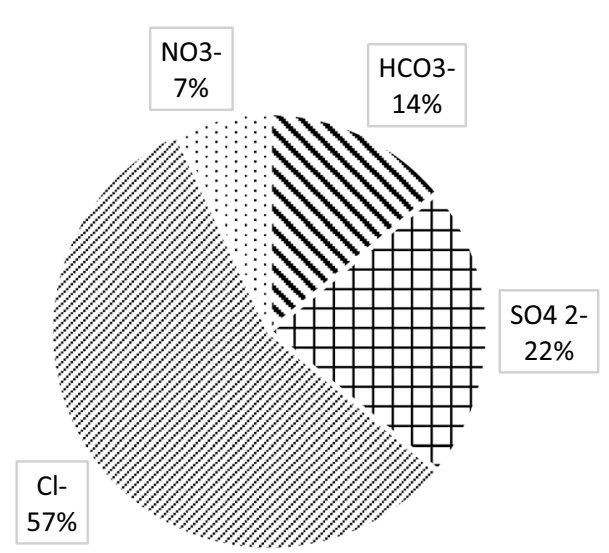

Fig. 3 Pie diagram of median values of major ions

\section{Hydrochemical evaluation}

The geochemical variations in the ionic concentrations in the groundwater can easily be understood when they are plotted along an $X-Y$ coordinate (Guler and Thyne 2004). Results from the chemical analyses were used to identify the geochemical processes and mechanisms in the groundwater aquifer system. The chemical data of the groundwater samples are plotted for $\mathrm{Ca}^{2+}+\mathrm{Mg}^{2+}$ versus $\mathrm{HCO}_{3}{ }^{-}-\mathrm{CO}_{3}{ }^{2-}$ diagram (Fig. 4a). The majority of data fall above the equiline (1:1), which suggests that an excess of alkalinity in the water has been balanced by alkalis $\left(\mathrm{Na}^{+}+\mathrm{K}^{+}\right)$, while the sample points lie below the equiline in a plot of $\mathrm{Ca}^{2+}+\mathrm{Mg}^{2+}$ versus total cation (TC) (Fig. 4b). The graph of $\mathrm{Ca}^{2+}+\mathrm{Mg}^{2+}$ versus TC shows most of the samples far below the theoretical line $(1: 1 ;$ Fig. $4 b)$, indicating an increasing contribution of alkalis to the major ions caused by silicate weathering (Subba Rao 2008). In a plot of $\mathrm{Na}^{+}+\mathrm{K}^{+}$versus TC (Fig. 4c), the chemical data of the samples fall below the equiline and above the $\mathrm{Na}^{+}+\mathrm{K}^{+} / 0.50 \mathrm{TC}$ line. This leads to infer that the supply of cations via silicate weathering and/or soil salts is more significant (Stallard and Edmond 1983), whereas the increase in alkalis with a simultaneous increase in $\mathrm{Cl}^{-}+\mathrm{SO}_{4}{ }^{2-}$ (Fig. 4d) reflects a common source for these ions from the dissolution of soil salts (Sarin et al. 1989; Datta and Tyagi 1996). The observed excess of $\mathrm{Na}^{+}$over $\mathrm{K}^{+}$is because of the greater resistance of $\mathrm{K}^{+}$to chemical weathering and its adsorption on clay minerals (Subba Rao 2008). Most of the samples have a $\mathrm{Na}^{+} / \mathrm{Cl}^{-}$ratio around or above 1 , indicating that an ion exchange process is prevalent in the study area (Fig. 4e) (Kumar et al. 2006). The evidence for ion exchange in the development of salinization can lead to the release of $\mathrm{Na}^{+}$from clay products, replacing $\mathrm{Ca}^{2+}$ that is present in groundwater. Figure $4 \mathrm{f}$ shows the ion exchange reactions, where $\mathrm{Na}^{+}$is plotted against $\mathrm{Ca}^{2+}$, in which $\mathrm{Ca}^{2+}$ levels are observed between

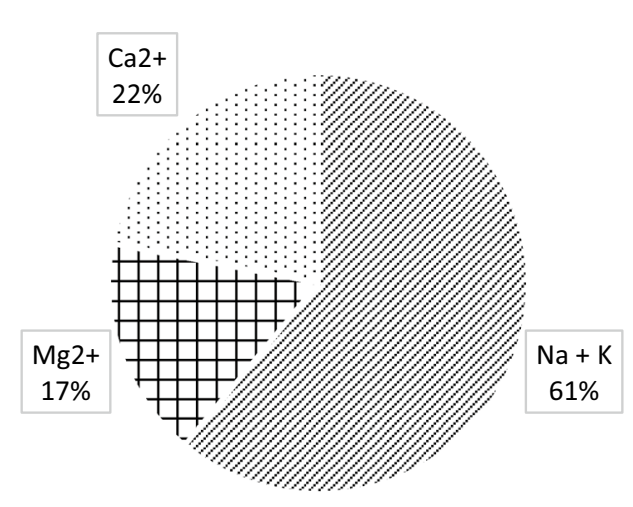

2.3 and $28 \mathrm{meq} / \mathrm{l}$, while $\mathrm{Na}^{+}$levels are found between 2.8 and $54 \mathrm{meq} / \mathrm{l}$. Hence, the ion exchange process appears as responsible for contributing higher concentration of $\mathrm{Na}^{+}$in the groundwater. If the ion exchange is the only controlling process of groundwater composition, the relation between $\left(\mathrm{Ca}^{2+}+\mathrm{Mg}^{2+}\right)-\left(\mathrm{SO}_{4}{ }^{2-}+\mathrm{HCO}_{3}{ }^{-}\right)$and $\mathrm{Na}^{+}-\mathrm{Cl}^{-}$should show the negative linear trend with a slope of unity, considering the participation of cations in the ion exchange reaction (Fisher and Mullican 1997).

In Fig. 4g, the samples show a trend of $\left(\mathrm{Ca}^{2+}+\mathrm{Mg}^{2+}\right)-\left(\mathrm{SO}_{4}{ }^{2-}+\mathrm{HCO}_{3}{ }^{-}\right)$versus $\mathrm{Na}^{+}-\mathrm{Cl}^{-}$with a negative slope of less than unity, but they spread above and below the linear trend. This suggests that the controlling of groundwater quality depends not only on the involvement of ion exchange process but also on the involvement of other processes. Otherwise, the spreading of sample points above and below the linear trend should not be expected. The graph of $\mathrm{Ca}^{2+}+\mathrm{Mg}^{2+}$ versus $\mathrm{SO}_{4}{ }^{2-}+\mathrm{HCO}_{3}{ }^{-}$will feature a nearly 1:1 line if dissolutions of calcite, dolomite, and gypsum are the dominant reactions in the system (Srivastava and Ramanathan 2008). Ion exchange tends to shift the points right because of the excess of $\mathrm{SO}_{4}{ }^{2-}+\mathrm{HCO}_{3}{ }^{-}$ions, which may be due to anthropogenic input in the groundwater system (Cerling et al.1989; Fisher and Mullican 1997). The graph of $\mathrm{Ca}^{2+}+\mathrm{Mg}^{2+}$ versus $\mathrm{SO}_{4}{ }^{2-}+\mathrm{HCO}_{3}{ }^{-}$(Fig. $4 \mathrm{~h}$ ) shows that nearly all of the samples fall above the 1:1 ratio line and show a deficiency of $\mathrm{Ca}^{2+}+\mathrm{Mg}^{2+}$ relative to $\mathrm{SO}_{4}{ }^{2-}+\mathrm{HCO}_{3}{ }^{-}$. Therefore, $\mathrm{Na}^{+}$must balance the excess of the negative charge of $\mathrm{SO}_{4}{ }^{2-}$ and $\mathrm{HCO}_{3}{ }^{-}$ions. Higher concentration of $\mathrm{Na}^{+}$in the groundwater is an index of ion exchange process.

\section{Hydrochemical facies}

The term hydrochemical facies is used to describe the bodies of groundwater in an aquifer that differ in their chemical composition. The facies is a function of the lithology,

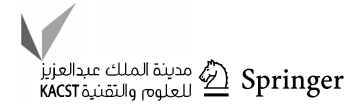



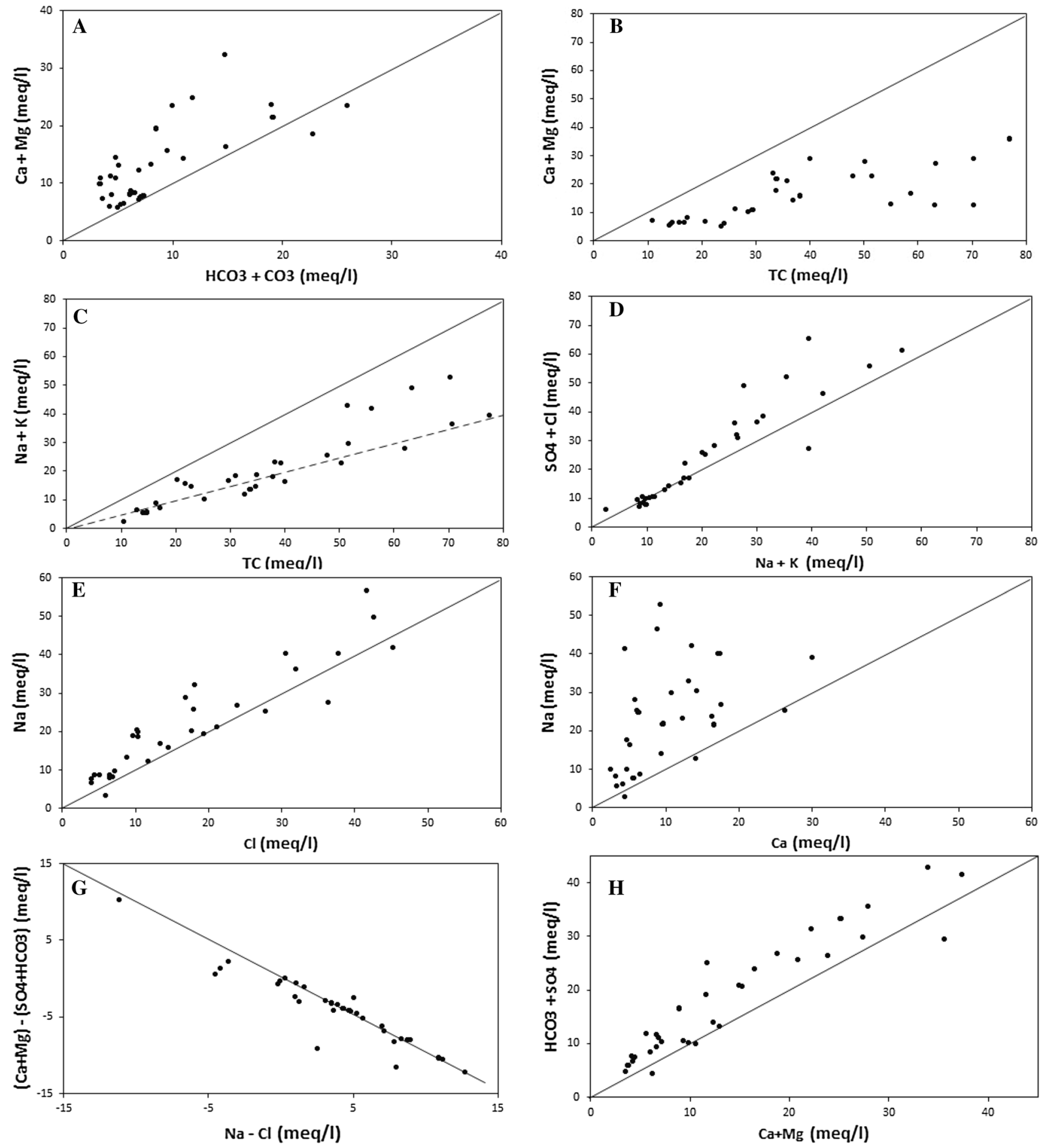

Fig. 4 Graphs of different parameters (solid and dashed lines denotes 1:1 and 1:0.5, respectively)

solution kinetics, and flow patterns of the aquifer (Raju et al. 2009). Large tables of analytical data are usually difficult to interpret regarding the variations in water quality. Graphs are useful for this purpose, and several specialized types are in use. Piper diagram is one of them. It provides a convenient method to classify and compare water types based on the ionic composition of different water samples (Chkirbenea et al. 2009). The values obtained from the groundwater sample analyzing and their plot on Piper's diagrams (Piper 1944) reveal that the major cation is $\mathrm{Na}^{+}$and the anion is $\mathrm{Cl}^{-}$. In the study area, the major groundwater types are $\mathrm{Na}-\mathrm{Cl}$ and mixed $\mathrm{Ca}, \mathrm{Mg}-\mathrm{Cl}$ types that the alkalis $\left(\mathrm{Na}^{+}\right.$, 


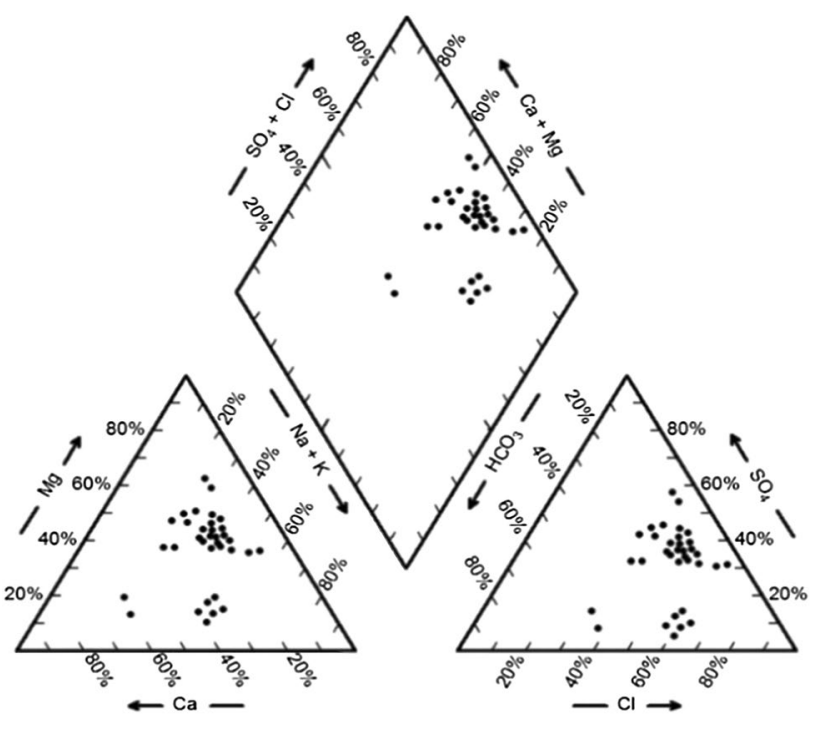

Fig. 5 Chemical facies of groundwater in Piper diagram

$\mathrm{K}^{+}$) are significantly dominating over the alkaline earth metals $\left(\mathrm{Ca}^{2+}, \mathrm{Mg}^{2+} ;\right.$ Fig. 5). The $\mathrm{Na}-\mathrm{Cl}$ water type in the study area is due to the low velocity of groundwater, ion exchange, long time contacts of water, and formations as well as the type of the rocks.

\section{Saturation index}

Saturation indices are used to evaluate the degree of equilibrium between water and minerals. Changes in saturation state are useful to distinguish different stages of hydrochemical evolution and help identify which geochemical reactions are important in controlling water chemistry (Coetsiers and Walraevens 2006; Drever 1997; Langmuir 1997). The saturation indices were determined using the hydrogeochemical equilibrium model, PHREEQC for Windows (Parkhurst and Appelo 1999). The saturation index of a mineral is obtained from Table 2c equation (Garrels and Mackenzie 1967), where IAP is the ion activity product of the dissociated chemical species in solution and $\mathrm{Kt}$ is the equilibrium solubility product for the chemical involved at the sample temperature. An index (SI), less than zero, indicating that the groundwater is under-saturated with respect to that particular mineral. Such a value could reflect the character of water from a formation with an insufficient amount of the mineral for the solution or short residence time. An index (SI), greater than zero, specifies that the groundwater being supersaturated with respect to the particular mineral phase and, therefore, incapable of dissolving more of the mineral. Such an index value reflects groundwater discharging from an aquifer containing ample amount of the mineral with sufficient resident time to reach equilibrium. Nonetheless, supersaturating can also be produced by other factors that

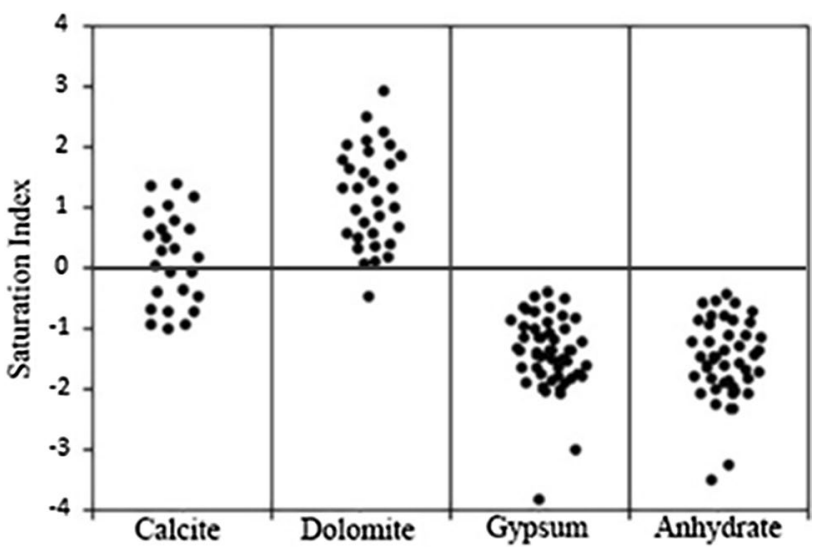

Fig. 6 Plots of saturation indices with respect to calcite, dolomite, gypsum, and anhydrate minerals

include incongruent dissolution, common ion effect, evaporation, the rapid increase in temperature, and $\mathrm{CO}_{2}$ exsolution (Appelo and Postma 1996; Langmuir 1997). In Table 1, the SI for calcite, dolomite, anhydrite, and gypsum is shown. Figure 6 shows the plots of SI for all the investigated water. Nearly, all water samples were supersaturated with respect to calcite and dolomite and all samples under-saturated with respect to gypsum and anhydrite, suggesting that these carbonate mineral phases may have influenced the chemical composition of the study area. In $\mathrm{Na}-\mathrm{Cl}$ water type, the mean values of $\mathrm{SI}_{\text {cal }}, \mathrm{SI}_{\mathrm{dol}}, \mathrm{SI}_{\mathrm{gyp}}, \mathrm{SI}_{\text {anhy }}$ are $0.35,0.85,-1.17$, and -1.34 , respectively.

\section{Drinking and irrigation water quality}

The analytical results have been evaluated to ascertain the suitability of groundwater in the study area for drinking and agricultural uses. The drinking water quality is evaluated by comparing with the specifications of TH and TDS set by the WHO (2011). According to WHO (2011) specification, TDS up to $500 \mathrm{mg} / \mathrm{l}$ is the highest desirable and up to $1500 \mathrm{mg} / \mathrm{l}$ is maximum permissible (Table 4). Based on this classification, $27 \%$ of samples belong to maximum permissible category, and the remaining samples are exceeding the maximum allowable limits. The classification of groundwater based on total hardness (TH) (Sawyer and McCartly 1967) shows that all of the groundwater samples fall in the very hard water category (Table 4). Maximum allowable limit of TH for drinking is $500 \mathrm{mg} / \mathrm{l}$, and the most desirable limit is $100 \mathrm{mg} / \mathrm{l}$ as per the WHO international standard. Based on this classification, it indicates that $73 \%$ samples exceed the maximum allowable limits; such water (water with $\mathrm{TH}$ greater than $80 \mathrm{mg} / \mathrm{l}$ ) cannot be used for domestic purposes because it coagulates soap lather.

The development and maintenance of successful irrigation projects involve not only the supplying of irrigation

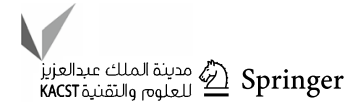


Table 4 Classification of groundwater based on total hardness (TH), electrical conductivity (EC), chloride concentration, sodium adsorption ratio (SAR), sodium percent $(\% \mathrm{Na})$, and residual sodium carbonate (RSC)

\begin{tabular}{|c|c|c|c|}
\hline Parameters & Range & Water class & $\begin{array}{l}\text { Percent } \\
\text { of sam- } \\
\text { ples }\end{array}$ \\
\hline \multirow[t]{5}{*}{ Na \% (Wilcox 1955) } & $0-20$ & Excellent & - \\
\hline & $20-40$ & Good & - \\
\hline & $40-60$ & Permissible & 5 \\
\hline & $60-80$ & Doubtful & 62 \\
\hline & 80 & Unsuitable & 33 \\
\hline \multirow[t]{4}{*}{ SAR (Richards 1954) } & $<10$ & Excellent & 83 \\
\hline & $10-18$ & Good & 11 \\
\hline & $18-26$ & Doubtful & 6 \\
\hline & 26 & Unsuitable & - \\
\hline \multirow[t]{5}{*}{ EC (Wilcox 1955) } & 250 & Excellent & - \\
\hline & $250-750$ & Good & - \\
\hline & $750-2000$ & Permissible & 22 \\
\hline & $2000-3000$ & Doubtful & 53 \\
\hline & 3000 & Unsuitable & 25 \\
\hline \multirow[t]{3}{*}{ RSC (Richards 1954) } & $<1.25$ & Good & 5 \\
\hline & $1.25-2.50$ & Doubtful & 16 \\
\hline & 2.5 & Unsuitable & 79 \\
\hline \multirow[t]{4}{*}{ TH (Sawyer and McCarthy 1967) } & $<75$ & Soft & - \\
\hline & $75-150$ & Moderately hard & - \\
\hline & $150-300$ & Hard & - \\
\hline & 300 & Very hard & 100 \\
\hline \multirow[t]{8}{*}{$\mathrm{Cl}^{-}$Classification (Stuyfzand 1989) } & $<0.14$ & Extremely fresh & - \\
\hline & $0.14-0.85$ & Very fresh & - \\
\hline & $0.85-4.23$ & Fresh & 11 \\
\hline & $4.23-8.46$ & Fresh brackish & 27 \\
\hline & $8.46-28.21$ & brackish & 42 \\
\hline & $28.21-282.06$ & Brackish salt & 20 \\
\hline & $282.06-564.13$ & Salt & - \\
\hline & $>564.13$ & Hypersaline & - \\
\hline
\end{tabular}

water to the land but also the control of salt and alkali in the soil (Haritash et al. 2008). Salinity and indices such as SAR, \% Na, RSC, and PI are important parameters for determining the suitability of groundwater for agricultural uses (Srinivasa Gowd 2005; Raju 2007). EC is a good measure of salinity hazard to crops as it reflects the TDS in groundwater. The US Salinity Laboratory (1954) classified groundwater on the basis of EC (Table 4). Based on this classification, $22 \%$ of samples belong to the permissible category, $53 \%$ doubtful category, and $25 \%$ unsuitable category. Stuyfzand (1989) classified water on the basis of $\mathrm{Cl}^{-}$ion concentration into eight divisions as shown in Table 3. Based on this classification, $10 \%$ of groundwater samples were fresh, $27 \%$ fresh brackish, 42 and $20 \%$ were brackish salt and salt on the basis of $\mathrm{Cl}^{-}$concentration. SAR is an important parameter for determining the suitability of groundwater for irrigation because it is a measure of alkali/sodium hazard to crops (Subramani et al. 2005). SAR is defined by using Table 1a equation, where all ionic concentrations are expressed in meq/l. The SAR values range from 1.2 to 19.2. According to the Richards (1954) classification based on SAR values (Table 4 ), $83 \%$ of samples belong to the excellent category, $11 \%$ of them belong to good category and the remaining samples belong to the doubtful category. SAR can indicate the degree to which irrigation water tends to enter cation exchange reactions in soil. Sodium replacing adsorbed calcium and magnesium is a hazard as it causes damage to the soil structure and becomes compact and impervious (Raju 2007). In all natural waters, percent of sodium content is a common parameter to assess its suitability for agricultural purposes (Wilcox 1948). The $\% \mathrm{Na}$ is obtained by using Table $1 \mathrm{~b}$ equation, where all ionic concentrations are expressed in meq/l, according to the Wilcox (1955) classification based on $\% \mathrm{Na}$ values (Table 4 ), $5 \%$ of samples belong to the good category, $62 \%$ of them belong to permissible category, and the remaining samples belong to the doubtful 
category. RSC has been calculated to determine the hazardous effect of carbonate and bicarbonate on the quality of water for agricultural purposes and has been determined by using Table $1 \mathrm{~d}$ equation, where all ionic concentrations are expressed in meq/l (Eaton 1950). The classification of irrigation water according to the RSC values is water containing more than $2.5 \mathrm{meq} / \mathrm{l}$ of RSC are not suitable for irrigation, while those having $1.25-2.5 \mathrm{meq} / \mathrm{l}$ are doubtful and those with less than $1.25 \mathrm{meq} / \mathrm{l}$ are good for irrigation (Table 4). Based on this classification, 5\% samples belong to the good category, $16 \%$ samples belong to the doubtful category, and $79 \%$ belong to unsuitable category. The PI values also indicate that the groundwater is unsuitable for irrigation. It is defined by using Table 1e equation, where all the ions are expressed in meq/l (Ragunath 1987). WHO (2011) uses a criterion for assessing the suitability of water for irrigation based on PI. According to PI values, the groundwater in the study area can be designated as class II (25-75\%) indicating that the groundwater is unsuitable for irrigation excepting the two samples, which was classified as class I ( $>75 \%)$.

In summary, west and north of MSC, albeit high concentration of dissolved ions, are suitable locations for drinking water wells, although east and north of MSC are relative appropriate place for irrigational wells. According to these results, authorities could manage groundwater resources properly for various demands in the study area.

\section{Conclusions}

Interpretation of hydrochemical analysis reveals that the groundwater in the study area is very hard, fresh to brackish and alkaline in nature. The sequence of the abundance of the major ions is in the following order: $\mathrm{Na}^{+}>\mathrm{Ca}^{2+}>\mathrm{Mg}^{2+}>\mathrm{K}^{+}$ and $\mathrm{Cl}^{-}>\mathrm{HCO}_{3}{ }^{-}>\mathrm{SO}_{4}{ }^{2-}>\mathrm{NO}_{3}{ }^{-}$. Alkalis slightly exceed alkali earths, and strong acids exceed weak acids. The compositional relations and mineral saturation states indicate that the dominant control of associated hydrogeochemical processes is the dissolution of evaporite minerals such as halite and gypsum, ion exchange, and the residence time of the groundwater in contact with rock materials. Hydrochemical studies indicate that the concentration of nitrate is higher than permissible limit $(50 \mathrm{mg} / \mathrm{l})$ in most of the groundwater collected from hand-pumped wells. The chief sources of nitrate pollution in the study area are agricultural activities, septic tanks, and human and animal wastes. Septic systems, animal waste, and fertilizer are all potential sources of nitrate contamination. High values of $\mathrm{SO}_{4}{ }^{2-}$ in samples indicated that $\mathrm{SO}_{4}{ }^{2-}$ derived from chemical fertilizers and dissolution of sulfate-bearing minerals, especially gypsum and anhydrite, that present in the lithological units. The $\mathrm{F}^{-}$values of samples are within the prescribed limit of WHO guideline, $1.5 \mathrm{mg} / \mathrm{l}$, so there is no potential hazard of
$\mathrm{F}^{-}$content in groundwater samples in MSC. In the study area, the dominant hydrochemical facies of groundwater is $\mathrm{Na}-\mathrm{Cl}$. Ionic concentrations, TDS, EC, and water quality suggest that groundwater residence time is primarily controlled by the occurrence of different hydrochemical facies. Assessment of water samples according to exceeding the permissible limits prescribed by WHO for drinking purposes indicated that groundwater in the study area is chemically unsuitable for drinking uses. Assessment of water samples from the calculation of chemical indices like SAR, $\% \mathrm{Na}$, RSC, and PI indicated that groundwater in the study area is chemically doubtful to unsuitable for irrigation.

Open Access This article is distributed under the terms of the Creative Commons Attribution 4.0 International License (http://creativeco mmons.org/licenses/by/4.0/), which permits unrestricted use, distribution, and reproduction in any medium, provided you give appropriate credit to the original author(s) and the source, provide a link to the Creative Commons license, and indicate if changes were made.

\section{References}

Appelo CAJ, Postma D (1996) Geochemistry: groundwater and pollution, 2nd edn. Balkema, Rotterdam, p 321

Ashworth JM (2005) Groundwater assessment of the downstream sections of the Balkh and Kholum Watersheds. Water and Energy Ministry, Govt. of Afghanistan, Kabul

Brookfield ME, Hashmat A (2001) The geology and petroleum potential of the North Afghan platform and adjacent areas (northern Afghanistan, with parts of southern Turkmenistan, Uzbekistan and Tajikistan). Earth Sci Rev 55:41-71

Cerling TE, Pederson BL, Damm KLV (1989) Sodium calcium ion exchange in weathering of shale; implication for global weathering budget. Geology. https://doi.org/10.1130/0091-7613(1989)

Chkirbenea A, Tsujimurab M, Charefa A, Tanakab T (2009) Hydrogeochemical evolution of groundwater in an alluvial aquifer: Case of Kurokawa aquifer, Tochigi prefecture, Japan. Desalination https ://doi.org/10.1016/j.desal.2008.04.057

Coetsiers M, Walraevens K (2006) Chemical characterization of the neogene aquifer, Belgium. Hydrogeol J. https://doi.org/10.1007/ s10040-006-0053-0

Dastyar AH, Bakhshi NA, Qadari MK (1990) Mesozoic and Cenozoic of the southern part of the Afghan-Tajik Basin and stratigraphic correlation between sedimentary basins of the ESCAP region, $v$. 14, ESCAP atlas of stratigraphy-Afghanistan, Australia, Mineral Resources Development Series No 58: 24-32

Datta PS, Tyagi SK (1996) Major ion chemistry of groundwater in Delhi area: chemical weathering processes and groundwater flow regime. J Geol Soc India 47:179-188

Drever JI (1997) The geochemistry of natural waters: surface and groundwater environments. Prentice Hall, Upper Saddle River, p 436

Eaton FM (1950) Significance of carbonates in irrigation water. Soil Sci 69:123-133

Fisher RS, Mullican FW (1997) Hydrochemical evolution of sodiumsulfate and sodium-chloride groundwater beneath the Northern Chihuahuan Desert, Trans- Pecos, Texas, USA. Hydrogeol J. https ://doi.org/10.1007/s100400050102

Freeze RA, Cherry JA (1997) Groundwater. Prentice Hall, Englewood Cliffs 
Garrels R, Mackenzie F (1967) Origin of the chemical compositions of some springs and lakes: equilibrium concepts in natural water systems. American Chemical Society Publications, Washington

Gowd SS (2005) Assessment of groundwater quality for drinking and irrigation purpose: a case study of Peddavanka watershed, Anantapur District, Andhra Pradesh, India. Environ Geol. https://doi. org/10.1007/s00254-005-0009-z

Guler C, Thyne GD (2004) Hydrologic and geologic factors controlling surface and groundwater chemistry in Indian Wells-Owens Valley area, southeastern California, USA. J Hydrol. https://doi. org/10.1016/j.jhydrol.2003.08.019

Han D, Liang X, Jin M, Currell MJ, Han Y, Song X (2009) Hydrogeochemical indicators of groundwater flow systems in the Yangwu River Alluvial Fan, Xinzhou Basin, Shanxi, China. Environ Manag. https://doi.org/10.1007/s00267-009-9301-0

Haritash AK, Kaushik CP, Kaushik A, Kansal A, Yadav AK (2008) Suitability assessment of groundwater for drinking, irrigation and industrial use in some North Indian villages. Environ Monit Assess. https://doi.org/10.1007/s10661-007-0048-X

Karanth KR (1987) Groundwater assessment, development and management. McGraw Hill, New Delhi

Kato H, Nakagami K, Cooper M (2016) Participatory approaches to environmental management: future design for water resources management. In: Nakagami K, Kubota J, Setiawan B (eds) Sustainable water management. Springer, Singapore

Kumar M, Ramanathan AL, Rao, Kumar B (2006) Identification and evaluation of hydrogeochemical process in the groundwater environment of Delhi, India. Environ Geol. https://doi.org/10.1007/ s00254-006-0275-4

Kumar SK, Rammohan V, Sahayam JD, Jeevanandam M (2009) Assessment of groundwater quality and hydrogeochemistry of Manimuktha River basin, Tamil Nadu, India. Environ Monit Assess. https://doi.org/10.1007/s10661-008-0633-7

Langmuir D (1997) Aqueous environmental geochemistry. Prentice Hall, Upper Saddle River

Miskin LP (1968) Groundwater investigations for domestic and drinking purposes in Northern Regions of Afghanistan. Report on Results of Investigation carried by the Hydrogeological Division of the Oil and Gas Exploration Department, from June 1965 through March 1968. Water and Energy ministry, Govt. of Afghanistan, Kabul

Parkhurst DL, Appelo CAJ (1999) User's guide to PHREEQC (version 2) A computer program for speciation, batch reaction, one dimensional transport, and inverse geochemical calculations. USGS water-resources investigations report, pp 99-4259

Piper AM (1944) A graphic procedure in the geochemical interpretation of water analysis. Trans Am Geophys Union 25:914-928

Radojicic SS, Arsalan SM (1979) Balkh-Aqcha regional water supply scheme. Report on Groundwater Potential. Ministry of Public Health, Govt. of Afghanistan, Kabul

Ragunath HM (1987) Groundwater. Wiley, New Delhi

Raju NJ (2007) Hydrogeochemical parameters for assessment of groundwater quality in the upper Gunjanaeru River basin, Cuddapah District, Andhara Pradesh, South India. Environ Geol. https ://doi.org/10.1007/s00254-006-0546-0

Raju NJ, Ram P, Dey S (2009) Groundwater quality in the lower Varuna river basin, Varanasi District, Uttar Pradesh. J Geol Soc India. https://doi.org/10.1007/s12594-009-0074-0

Rao NS (2008) Factors controlling the salinity in groundwater in parts of Guntur district, Andhra Pradesh, India. Environ Monit Assess. https://doi.org/10.1007/s10661-007-9801-4
Richard LA (1954) Diagnosis and improvement of saline and alkali soils. U.S. Department of Agriculture, Washington

Ruleman CA, Crone AJ, Machette MN, Haller KM, Rukstales KS (2007) Map and database of probable and possible quaternary faults in Afghanistan. http://pubs.usgs.gov/of/2007/1137/

Russian Scientists (1969-1997) Hydro-geological investigations reports of oil and gas deportment for North of Afghanistan. USSR

Sarin MM, Krishnaswami S, Dill K, Somayajulu BLK, Moore WS (1989) Major ion chemistry of the Ganga-Brahmaputr river system: weathering processes and fluxes to the Bay of Bengal. Geochem Cosmochim Acta. https://doi.org/10.1016/00167037(89)90205-6

Sawyer GN, McCartly DL (1967) Chemistry of sanitary engineers. McGraw Hill, New York

Shroder F (2014) Natural resources in Afghanistan: geographic and geologic perspectives on centuries of conflict. Elsevier, San Diego

Shroder F, Ahmadzai S (2016) Transboundary water resources in Afghanistan: climate change and land-use implications. Elsevier, Amsterdam

Shygonskyi V, Shygonska N (2016) Assessment of drinking water quality as a factor affecting human health in Zhytomyr Region. Kontakt. https://doi.org/10.1016/j.kontakt.2016.05.007

Srivastava SK, Ramanathan AL (2008) geochemical assessment of groundwater quality in vicinity of Bhalswa landfill, Delhi, India, using graphical and multivariate statistical methods. Environ Geol. https://doi.org/10.1007/s00254-007-0762-2

Stallard RF, Edmond JM (1983) Geochemistry of the Amazon Riverthe influence of the geology and weathering environment on the dissolved load. J Geophys Res. https://doi.org/10.1029/jc088ic14p 09671

Stuyfzand PJ (1989) Nonpoint source of trace element in potable groundwater in Netherland. In: Proceedings of the 18th TWSA Water Working, Testing and Research Institute. KIWA, Nieuwegein

Subramani T, Elango L, Damodarasamy SR (2005) Groundwater quality and its suitability for drinking and agricultural use in Chithar River Basin, Tamil Nadu, India. Environ Geol. https://doi. org/10.1007/s00254-005-1243-0

Ulmishek GF (2004) Petroleum geology and resources of the Amu Darya Basin, Turkmenistan, Uzbekistan, Afghanistan and Iran. USGS Bulletin

USAID (2009) Commercialization of Afghanistan water and sanitation activity (CAWSA), assessment report MSC water supply (CAWSA). Retrieved from: www. ijens. org/ Vol_12_I_06/1214406-8585-IJCEEIJENS.pdf

USGS (2005) Geological map of quadrangles (3666), Balkh (219), Mazar-i- Sharif (220), Qarqin (213) and Hazara Toghal (214) quadrangles map, Afghanistan. http://pubs.usgs.gov/ of/2005/1093/A/index.html

WHO (2011) Guidelines for drinking-water quality. World Health Organization, Geneva

Wilcox LV (1948) The quality of water for irrigation use. U.S. Department of Agriculture, Washington

Wilcox LV (1955) Classification and use of irrigation water. US Geol Dept Agri Arc 969:19

Publisher's Note Springer Nature remains neutral with regard to jurisdictional claims in published maps and institutional affiliations. 